NBER WORKING PAPER SERIES

\title{
ALLOCATING HOUSEHOLD TIME: WHEN DOES EFFICIENCY IMPLY SPECIALIZATION?
}

\author{
Robert A. Pollak \\ Working Paper 19178 \\ http://www.nber.org/papers/w19178 \\ NATIONAL BUREAU OF ECONOMIC RESEARCH \\ 1050 Massachusetts Avenue \\ Cambridge, MA 02138 \\ June 2013
}

This is the second of two theoretical papers on household time allocation in general and specialization in particular. Preliminary versions of portions of these papers were presented at the PAA in New York, SOLE in Chicago, IZA in Bonn, ESPE in Chicago, the AEA in New Orleans, the University of Missouri, Duke University, Collegio Carlo Alberto in Torino, the University of Cergy-Pontoise, the University of Chicago, Mount Holyoke College, Cornell, UCLA, the University of Massachusetts in Amherst, the University of Maryland conference on International Perspectives on Time Use, and Uppsala University. I am grateful to Paula England, Shelly Lundberg, Mark Rosenzweig, Leslie Stratton, Yoram Weiss, and Randy Wright for conversations and comments. This research was supported in part by the University of Bergen and the Research Council of Norway as part of the AGEFAM project, and by the Eunice Kennedy Shriver National Institute of Child Health \& Human Development, National Institutes of Health (RO1HD056207-01A2). I am grateful to them for their support, but I alone am responsible for the views expressed. The views expressed herein are those of the author and do not necessarily reflect the views of the National Bureau of Economic Research.

NBER working papers are circulated for discussion and comment purposes. They have not been peerreviewed or been subject to the review by the NBER Board of Directors that accompanies official NBER publications.

(C) 2013 by Robert A. Pollak. All rights reserved. Short sections of text, not to exceed two paragraphs, may be quoted without explicit permission provided that full credit, including $(\mathbb{C}$ notice, is given to the source. 
Allocating Household Time: When Does Efficiency Imply Specialization?

Robert A. Pollak

NBER Working Paper No. 19178

June 2013, Revised March 2014

JEL No. D13,J22

\begin{abstract}
When does efficiency in the household imply specialization? For example, if we recognize two sectors, "market" and "household," when does efficiency imply that one spouse specializes in the market and the other in the household? If efficiency did imply specialization, then egalitarian marriages would be inefficient and an equity-efficiency tradeoff inescapable. This paper clarifies the roles that household technology and human capital play in reaching conclusions about specialization.

The critical assumption that leads to the specialization conclusion in Becker's Treatise on the Family is that spouses' time inputs are perfect substitutes in household production. With no further assumptions (other than efficiency and the absence of process preferences) perfect substitutes imply specialization. Although some of Becker's proofs appear to rely on households optimally adjusting spouses' stocks of market and household human capital, the specialization conclusion does not: with perfect substitutes, efficiency implies specialization even when each spouse's stocks of human capital are fixed, regardless of the levels at which they are fixed. Other assumptions about household technology also imply the specialization conclusion. I prove that (again in the absence of process preferences) if the household technology is "additive" and exhibits constant returns to scale, then efficiency implies specialization.
\end{abstract}

\author{
Robert A. Pollak \\ Washington University in St. Louis \\ Arts and Sciences \\ and the Olin Business School \\ Campus Box 1133 \\ 1 Brookings Drive \\ St. Louis, MO 63130-4899 \\ and NBER \\ pollak@wustl.edu
}




\section{Introduction}

When does efficiency in the household imply specialization? More specifically, if we recognize two sectors, "market" and "household," when does efficiency imply "sector specialization"? Becker $(1981,1991)$ raised the issue of specialization in his Treatise on the Family. ${ }^{1}$ This paper revisits it.

Specialization has two distinct meanings. Informally, "specialization" is shorthand for time allocation and the division of labor in multiple-person households. Formally, as in the "specialization theorems" in Chapter 2 of Becker's Treatise, "specialization" is an extreme time allocation in which, for example, one spouse works only in the household and the other works only in the market. More precisely, specialization is a "corner solution" to the household's time allocation problem in which one spouse (and perhaps both spouses) works in only one sector. This paper is about "specialization theorems" and thus about specialization in the second, formal sense.

If efficiency did imply specialization, then egalitarian marriages would be inefficient and an equity-efficiency tradeoff inescapable. ${ }^{2}$ The chain connecting distribution in marriage to the specialization claim has two links: (1) the assumption that distribution between spouses depends on bargaining in marriage and (2) the assumption that bargaining power in marriage depends on earnings or wages. If equity depends on parity in bargaining

\footnotetext{
${ }^{1}$ Hereafter I cite the Treatise as Becker (1991). Specialization is discussed in Chapter 2 of the Treatise, entitled "Division of Labor in Households and Families," which first appeared in the 1981 edition. Many papers credit Becker (1965), "A Theory of the Allocation of Time," with raising the specialization issue, perhaps because in retrospect the division of labor and specialization seem obvious grist for the household production mill. But what seems obvious in retrospect was not obvious in prospect. Becker (1965) devotes only a single paragraph to multiple-person households; the rest of that paper, like Chapter 1 of the Treatise, assumes single-person households, so issues of specialization and the division of labor cannot arise. A decade later, Pollak and Wachter (1975) missed the opportunity to develop the household production model in the "obvious" direction of the division of labor and specialization.

${ }^{2}$ I define specialization formally and distinguish between specialization and strong specialization in section 2.
} 
power and bargaining power depends on earnings or wages, then equity requires that both spouses work in the market. But if efficiency implied specialization and both spouses work in the market, it follows that one spouse must do all the housework. Hence, if efficiency implies specialization, these two assumptions imply that efficient couples must choose between unequal bargaining power and an "inequitable" division of household work: equity and efficiency would be incompatible. ${ }^{3}$ Although economists will be reluctant to accept the claim that an unequal division of household work is prima facie evidence of unfairness, the failure of one spouse to accumulate market human capital does have implications for future bargaining power. These distributional implications account for the continuing ability of the specialization claim to generate controversy. ${ }^{4}$ The availability of data, especially U.S. data from the American Time Use Survey (ATUS), has been a major impetus to empirical time use research by sociologists and economists. ${ }^{5}$

In the Treatise, Becker identifies a class of household technologies for which efficiency implies specialization, namely, technologies in which the time inputs of husbands

\footnotetext{
${ }^{3}$ Although the core of Becker's specialization argument is gender neutral, Becker famously argues that the efficient pattern of specialization is gendered, with wives allocating time to household production and husbands allocating time to the market. Becker's argument is two-pronged. The first prong is the claim that gender serves as a focal point for premarital investments in sector-specific human capital: before entering the marriage market, females invest in household human capital and males in market human capital. The second prong shifts the focus from wives to mothers. The claim is that even without specialized premarital investments in household human capital, mothers, because of their ability to breast-feed infants, would slide down a slippery slope toward specialization in household production. That is, even if fathers and mothers were initially equally productive in home and market, the ability of mothers to breast-feed leads to an equilibrium in which the efficient pattern of specialization is gendered with mothers specializing in the household and fathers in the market. In this paper I focus on the core specialization claim, not on the provocative but somewhat peripheral gendering claim.

${ }^{4}$ On bargaining in marriage, see Manser and Brown (1980), McElroy and Horney (1981), and Lundberg and Pollak (1993). On egalitarian marriage, see Wax (1998). For the flavor of the extensive sociology literature on the division of labor in households, see Hochchild and Machung (1989), Brines (1994), England and Folbre (2005), and Bianchi, et al. (2012).

${ }^{5}$ For a description of the ATUS, see Hamermesh, Frazis, and Stewart (2005). Unfortunately, the ATUS reports the time use of only one respondent in each sampled household, making it difficult to investigate the division of labor within couples. Examples of recent work of time use by economists include Aguiar and Hurst (2007, 2009), Guryan, Hurst, and Kearney (2008), Hamermesh and Lee (2007), Ramey and Ramey (2010), Ramey (2009), and Ramey and Neville (2009).
} 
and wives are perfect substitutes. ${ }^{6}$ Although human capital appears to play a crucial role in Becker's analysis of specialization, it actually does not. In Pollak (2012) I show that if spouses' time inputs are perfect substitutes, then efficiency implies specialization even if each spouse's stocks of market or household human capital are fixed at arbitrary levels. In this paper I show that there is an additional class of household technologies for which efficiency implies specialization. More specifically, I show that if the household technology is "additive" and exhibits constant returns to scale, then efficiency implies specialization. As with perfect substitutes, additivity and constant returns to scale imply specialization even if each spouse's stocks of market or household human capital are fixed at arbitrary levels. Finally, I examine the relationship between human capital and specialization, arguing that whether human capital tips the scales in favor of specialization depends on the strength of human capital effects on wages and on productivity in the household.

If the "efficiency implies specialization claim" (the "specialization claim," for short) were true for all technologies, then the observed pattern of widespread nonspecialization (i.e., both husbands and wives work in both the market sector and the household sector) would be evidence of widespread inefficiency. Lundberg and Pollak (2007) show that the last half of the 20th century witnessed a substantial convergence in the time allocation patterns of men and women. According to the CPS, in 2008 the labor force participation rate for married men between 35 and 44 was slightly over 95 percent; the corresponding rate for married women is almost 74 percent. The gap in time allocated to housework narrowed, although it remains substantial. According to the 2005

\footnotetext{
${ }^{6}$ Following Becker, I focus on married couples. With some modification, the analysis applies to other types of multiple-person households.
} 
American Time Use Survey (ATUS), married men spend an average of slightly less than 11 hours a week doing housework; the corresponding rate for married women is about 16 hours a week. For many couples husbands and wives work in both the market sector and the household sector, and the time allocation pattern of these couples does not exhibit sector specialization. The time allocation patterns of these couples are not necessarily inefficient because the "efficiency implies specialization" claim does not hold for all household technologies. For example, the specialization conclusion need not hold when the household technology exhibits decreasing returns to scale or when there is more than a single household production activity (e.g., cooking, laundry, yard work, household repairs).

The paper proceeds as follows. Section 2 introduces notation and defines terms. In Section 3 I prove that, in the absence of process preferences, additivity and constant returns to scale imply the specialization conclusion. Section 4 argues that decreasing returns to scale in household production is plausible and shows that, even with additivity, the specialization conclusion need not hold when household technology exhibits decreasing returns. Section 5 considers multiple activities in the household sector and "activity specialization." I show that when there are m household activities, the sector specialization claim fails even with perfect substitutes: it is easy to construct examples in which efficiency requires one spouse to allocate time to $\mathrm{m}^{*}$ household activities, the other spouse to allocate time to the remaining $m-m^{*}$ activities, and both spouses to allocate time to the market. Section 6 discusses human capital and specialization. I show that in a dynamic setting, human capital can tip the scale in favor of specialization; whether it does so, however, depends on the strength of human capital effects on wages 
and on productivity in the household. Section 7 is a brief conclusion. In the appendix I discuss the specialization theorems from the Treatise on the Family.

\section{Specialization, Process Preferences, Perfect Substitutes, Additivity}

Time allocation in multiple-person households depends on three elements: preferences, constraints, and the household's "governance structure." ${ }^{7}$ For definiteness, I focus on married couple households, so that preferences means the preferences of both spouses. The constraints reflect the wage rates of both spouses, the prices of market goods, the household technology, and spouses' individual technologies. Individuals' technologies include the technologies to which the spouses would have access if they left the marriage. These technologies are important because in virtually all models individuals' technologies (i.e., the technologies to which they would have access if they left the marriage) determine the spouses' outside options and, in some models, also determine bargaining power. The "governance structure" determines the mapping from preferences and constraints into allocations of goods, commodities, and time. Examples of governance structures include Becker's altruist model and cooperative Nash bargaining. Chiappori's $(1988,1992)$ "collective model" can be interpreted as a reduced form corresponding to any model with a single-valued, Pareto-efficient solution.

In Pollak (2012) I discuss these three elements of the time allocation model as well as the meaning of specialization. Except in special cases, conclusions about time allocation (e.g., specialization) depend on all three elements -- preferences, constraints, and the governance structure -- and cannot be inferred from the constraints or a subset of the constraints (e.g., household technology).

\footnotetext{
${ }^{7}$ I ignore information structure which, as Randy Wright pointed out when he discussed a very early version of this paper, is an additional basic element.
} 
The distinction between goods and commodities is central to the household production model. Becker (1965) wrote: "Households will be assumed to combine time and market goods to produce more basic commodities that directly enter their utility functions." I denote the household production function for the commodity $\mathrm{z}$ by $\mathrm{g}\left[\mathrm{t}_{\mathrm{h}}, \mathrm{t}_{\mathrm{w}}, \mathrm{y}\right]$, where $t_{\mathrm{h}}$ and $t_{\mathrm{w}}$ denote the time inputs of the husband and wife into the production of $\mathrm{z} ; \mathrm{y}$ denotes the market goods used to produce $\mathrm{z} .^{8}$

For a commodity produced within the household, either both spouses allocate time to its production ("bilateral production") or only one spouse allocates time to its production ("unilateral production"). Bilateral production and unilateral production are properties of the spouses' time allocation and, except in special cases, they depend on preferences, constraints, and the governance structure. If a commodity is produced unilaterally, the relevant domain of the household production function consists of the values at which $t_{h}=$ 0 or $\mathrm{t}_{\mathrm{w}}=0 .{ }^{9}$ Thus, $\mathrm{g}\left[\mathrm{t}_{\mathrm{h}}, 0, \mathrm{y}_{\mathrm{h}}\right]$ and $\mathrm{g}\left[0, \mathrm{t}_{\mathrm{w}}, \mathrm{y}_{\mathrm{w}}\right]$ are the unilateral production functions.

"Essentiality" assumptions formalize the notion that positive output requires positive time inputs from one or both spouses.

\section{Strong Essentiality Assumption:}

$$
\mathrm{g}\left[0, \mathrm{t}_{\mathrm{w}}, \mathrm{y}_{\mathrm{w}}\right]=\mathrm{g}\left[\mathrm{t}_{\mathrm{h}}, 0, \mathrm{y}_{\mathrm{h}}\right]=0 \text { for all }\left\{\mathrm{t}_{\mathrm{h}}, \mathrm{t}_{\mathrm{w}}, \mathrm{y}_{\mathrm{h}}, \mathrm{y}_{\mathrm{w}}\right\} .^{10}
$$

That is, positive output requires positive time inputs from both spouses, as in the CobbDouglas household production function:

$$
\mathrm{g}\left[\mathrm{t}_{\mathrm{h}}, \mathrm{t}_{\mathrm{w}}, \mathrm{y}\right]=\mathrm{At}_{\mathrm{h}}{ }^{\beta \mathrm{h}} \mathrm{t}_{\mathrm{w}}{ }^{\beta \mathrm{w}} \mathrm{y}^{\gamma} \text {. }
$$

\footnotetext{
${ }^{8}$ My notation here differs from that in the Treatise and also from that in Pollak (2012).

${ }^{9}$ The claim that unilateral production is efficient requires comparing alternatives involving unilateral production with alternatives involving bilateral production.

${ }^{10}$ Equivalently, if $\mathrm{t}_{\mathrm{h}} \mathrm{t}_{\mathrm{w}}=0$, then $\mathrm{g}\left[\mathrm{t}_{\mathrm{h}}, \mathrm{t}_{\mathrm{w}}, \mathrm{y}\right]=0$ for all $\mathrm{y}$.
} 


\section{Weak Essentiality Assumption:}

$$
\mathrm{g}[0,0, \mathrm{y}]=0 \text { for all } \mathrm{y} \text {. }
$$

That is, positive output requires positive time inputs from at least one spouse. Throughout this paper, I assume that the household production function satisfies weak essentiality and, sometimes, that it also satisfies strong essentiality.

One or both spouses may work in the market, earning money to purchase market goods. I denote the total time that each spouse allocates to work by $\left\{\mathrm{T}_{\mathrm{h}}, \mathrm{T}_{\mathrm{w}}\right\}$ and the time that each spouse allocates to market work by $\left\{\mathrm{t}_{\mathrm{h} 0}, \mathrm{t}_{\mathrm{w} 0}\right\}$ so

$$
\mathrm{t}_{\mathrm{h}}+\mathrm{t}_{\mathrm{h} 0}=\mathrm{T}_{\mathrm{h}}
$$

and

$$
\mathrm{t}_{\mathrm{w}}+\mathrm{t}_{\mathrm{w} 0}=\mathrm{T}_{\mathrm{w}} .
$$

In my examples, I generally assume $\mathrm{T}_{\mathrm{h}}=\mathrm{T}_{\mathrm{w}}$. This assumption is consistent with the empirical "isowork" finding of Burda, Hamermesh, and Weil (2013) that "in rich nonCatholic countries, men and women [and married men and married women] average about the same amount of total work." I assume that there is only a single market good and normalize its price to $1 .{ }^{11}$ The quantity of the market good is given by

$$
\mathrm{x}=\mathrm{w}_{\mathrm{h}} \mathrm{t}_{\mathrm{h} 0}+\mathrm{w}_{\mathrm{w}} \mathrm{t}_{\mathrm{w} 0}+\mathrm{x}^{*}=\mathrm{w}_{\mathrm{h}}\left(\mathrm{T}_{\mathrm{h}}-\mathrm{t}_{\mathrm{h}}\right)+\mathrm{w}_{\mathrm{w}}\left(\mathrm{T}_{\mathrm{w}}-\mathrm{t}_{\mathrm{w}}\right)+\mathrm{x}^{*}
$$

where $\left\{\mathrm{w}_{\mathrm{h}}, \mathrm{w}_{\mathrm{w}}\right\}$ are the spouses' wage rates and $\mathrm{x}^{*}$ is nonlabor income. ${ }^{12}$

Market goods play two roles. They are (or may be) inputs into the production of commodities, and they are (or may be) arguments of the spouses' utility functions. I allow

\footnotetext{
${ }^{11}$ Unless the relative prices of market goods vary, we lose nothing by ignoring the multiplicity of market goods and restricting attention to a single, aggregate market good. As I argue in section 5, we lose quite a lot by ignoring the multiplicity of commodities.
} 
for the possibility that market goods enter the spouses' utility functions directly, unmediated by household time. ${ }^{13} 14$

To define "specialization," it is best to begin with its opposite.

Nonspecialization: With two sectors, home and market, we say there is nonspecialization if and only if both spouses allocate time to both sectors. ${ }^{15}$

Specialization: At least one spouse allocates time to only one sector. ${ }^{16}$ That is, specialization is any time allocation other than nonspecialization. (i.e., any time allocation in which both spouses do not allocate time to both sectors). This definition of specialization is consistent with standard usage in the economics of the family and analogous to usage familiar in international economics.

\footnotetext{
${ }^{12}$ Becker $(1965,1991)$ emphasizes the role of nonlabor inputs (e.g., calories, nutrients, sleep) as well as human capital as determinants of market wage rates and earnings. I ignore these effects because they do not affect the validity of the specialization claim.

${ }^{13}$ Although I have not done so, it is sometimes convenient to treat the market sector as if it were another household activity, while recognizing that the "technology" for "producing" the market good has a different structure than most household production activities. The usual assumption that spouses' wage rates are constants (i.e., independent of the time inputs of the spouses to the market sector) implies that the marginal product of labor in market work (i.e., the wage rate) is constant. Hence, under the usual assumption that individuals face market wage rates that are independent of the number of hours they allocate to market work, the implied "production function" for the market good is linear. Progressive taxes destroy the linearity of this relationship.

I have assumed that the market good enters the spouses' utility functions directly. If we insist that the arguments of the utility functions are "commodities," then we need to introduce an additional household production activity with the property that $\mathrm{g}\left[\mathrm{t}_{\mathrm{h}}, \mathrm{t}_{\mathrm{w}}, \mathrm{y}\right]=\mathrm{y}$ for all $\left\{\mathrm{t}_{\mathrm{h}}, \mathrm{t}_{\mathrm{w}}, \mathrm{y}\right\}$. This would, of course, violate the weak essentiality assumption. As Gershuny (2000) points out, Becker (1965) emphasized that consuming market goods takes time, an insight that has been largely eclipsed by the subsequent emphasis on household production rather than consumption technology. Gronau (1977, p. 1100) makes this point.

${ }^{14}$ Following Becker (1965), I ignore leisure and focus on the allocation of each spouse's total work time between market work and household work. Gronau (1977) introduced leisure into a single-person household production model. As Becker (1965) points out, with multiple household production activities, leisure is simply an additional time-intensive activity.

${ }^{15}$ The interpretation and analysis of the specialization claim is sensitive to whether we recognize more than one household activity. To focus on sector specialization, I assume that there is only one household production activity. This assumption is consistent with the discussion of specialization in Chapter 2 of the Treatise which recognizes only one household production activity. I discuss multiple household production activities in section 5. The discussion of household production in Chapter 1 of the Treatise, like the classic discussion in Becker (1965), recognizes multiple household production activities.

16 "Specialization" might be called "weak specialization."
} 
Strong specialization: Each spouse allocates time to only one sector. Strong specialization includes not only the case in which spouses allocate time to different sectors (e.g., husbands work only in the market; wives work only in the household), but also the case in which both spouses allocate all of their time to the same sector (e.g., both spouses allocate all of their time to the household). I call this case "superstrong specialization." ${ }^{17}$

Nonspecialization implies bilateral household production, but specialization opens up the possibility of unilateral household production. Putting aside superstrong specialization for the present, there are three cases with specialization:

1. if both spouses work in the household, then only one spouse works in the market; in this case, we have bilateral household production;

2. if both spouses work in the market, then only one spouse works in the household; in this case we have unilateral household production; ${ }^{18}$

3. each spouse allocates time to only one sector (i.e., strong specialization); in this case, we have unilateral household production.

With process preferences, individuals care how they spend their time. ${ }^{19}$ The validity of the specialization claim depends on assuming away process preferences or

\footnotetext{
${ }^{17}$ Superstrong specialization may at first seem pathological because we usually apply the household production model to working-age couples in which at least one spouse works in the market and at least one spouse works in the household. Retired or disabled couples in which both spouses work in the household and neither works in the market are obvious examples of superstrong specialization. Whether unemployed couples exemplify superstrong specialization depends on whether we classify job search as market work.

${ }^{18}$ Fixed costs associated with market work (e.g., commuting costs) make it less likely that specialization will involve both spouses working in the market (case 2). Among the few models that include fixed costs associated with market work are Cogan (1981) and Donald and Hamermesh (2009).

${ }_{19}$ In labor economics, the concept of process preferences, although not the terminology, goes back to Adam Smith. Juster and Stafford (1991) call these "psychic benefits" or "process benefits." "Process preferences" is a better term because it accommodates negative effects ("disbenefits") as well as positive
} 
restricting them so that they strengthen rather than weaken the incentives to specialize. When there are two or more household activities, process preferences may take the form of a preference for cooking rather than cleaning. ${ }^{20}$ When there is only one household activity, process preferences may take the form of a preference for dividing time in some ratio between the market and the household, or an individual may enjoy working in the market more than working in the household, or vice versa. Regardless of the household production technology, if both spouses have sufficiently strong preferences for allocating time to both sectors, then Pareto efficiency will require that they do so. ${ }^{21}$

The default assumption in the new home economics is the absence of process preferences. Without process preferences, individuals care only about the nominal outputs of home production (a clean house; a home-cooked meal) but not about how they spend their time (cleaning; cooking). With two sectors, market and household, the absence of process preferences implies that market work and household work are perfect substitutes in both spouses' utility functions. ${ }^{22}$ Each spouse cares about his or her total work time, but each is indifferent among all combinations of market work and household work that correspond to the same total; in terms of (dis)utility, "work is work." For the remainder of this paper, I assume the absence of process preferences.

effects. Rosen (1986) provides a modern discussion of non-pecuniary benefits and "equalizing differences" in wages.

${ }^{20}$ In the context of one-person households, Pollak and Wachter (1975, p. 256) emphasize that the allocation of time may depend on the direct utility associated with time spent in an activity: "time spent in many production activities is a direct source of utility as well as an input into a commodity."

${ }^{21}$ As Folbre (2004) points out, economists generally interpret Pareto efficiency in a way that ignores outcomes for children, except to the extent that these outcomes enter into their parents' utility functions. A broader notion of Pareto efficiency would take account of the preferences, interests, or well-being of children.

${ }^{22}$ Perfect substitutes in the spouses' utility functions is quite different from perfect substitutes in the household production function. Except when explicitly noted, in this paper perfect substitutes refers to the household production function. 
With perfect substitutes, an "efficiency factor" converts the time input of the wife into units comparable to the time input of the husband. That is, the marginal rate of (technical) substitution of the husband's time for the wife's time is constant. Although none of Becker's specialization theorems explicitly assumes perfect substitutes, the surrounding discussion and the proofs of several of the specialization theorems rely on perfect substitutes. $^{23}$ Formally, perfect substitutes imply a household production function of the form

$$
\mathrm{g}\left[\mathrm{t}_{\mathrm{h}}, \mathrm{t}_{\mathrm{w}}, \mathrm{y}\right]=\mathrm{G}\left[\mathrm{t}_{\mathrm{h}}+\alpha(\mathrm{y}) \mathrm{t}_{\mathrm{w}}, \mathrm{y}\right]
$$

where the "efficiency factor," $\alpha(y)$, converts the time input of the wife into units comparable with the time input of the husband. In Pollak (2012) I analyze in detail the implications of the perfect substitutes assumption and argue that the assumption that spouses' time inputs are perfect substitutes is implausible. In the absence of process preferences, if spouses' time inputs are perfect substitutes then, with no further assumptions about technology, efficiency implies specialization.

The perfect substitutes assumption is problematic for two reasons. First, because it is implausible, the perfect substitutes assumption severely limits the applicability of the specialization claim. $^{24}$ Second, because perfect substitutes imply specialization, the perfect substitutes assumption makes redundant the explicitly stated hypotheses of the specialization theorems in the Treatise and makes human capital irrelevant to the specialization claim. More precisely, in the absence of process preferences, if spouses'

\footnotetext{
${ }^{23}$ In Pollak (2012) I erroneously claimed that although Becker (1991) uses the perfect substitutes case to motivate his discussion of specialization, "his specialization theorems do not assume that spouses' time inputs are perfect substitutes." This is flat-out wrong. Most of Becker's specialization theorems assume perfect substitutes and the interpretations of the remaining theorems depend on the perfect substitutes assumption.

${ }^{24}$ Lundberg (2008) and Pollak (2012) elaborate this point.
} 
time inputs are perfect substitutes, then efficiency implies specialization. Full stop. That is, with perfect substitutes, additional assumptions (other than the absence of process preferences) are not needed to reach the specialization conclusion. But perfect substitutes is not the only assumption about household technology for which efficiency implies specialization. In section 3 I show that, in the absence of process preferences, if the household technology is "additive" and exhibits constant returns to scale, then efficiency requires specialization. Formally,

Additivity Assumption: The household technology is of the form

$$
\begin{aligned}
& \mathrm{g}\left[\mathrm{t}_{\mathrm{h}}, \mathrm{t}_{\mathrm{w}}, \mathrm{y}\right]=\max \left\{\mathrm{g}^{\mathrm{h}}\left[\mathrm{t}_{\mathrm{h}}, 0, \mathrm{y}_{\mathrm{h}}\right]+\mathrm{g}^{\mathrm{w}}\left[0, \mathrm{t}_{\mathrm{w}}, \mathrm{y}_{\mathrm{w}}\right]\right\} \\
& \text { subject to } \mathrm{y}_{\mathrm{h}}+\mathrm{y}_{\mathrm{w}} \leq \mathrm{y} .
\end{aligned}
$$

If the household technology is additive and both spouses engage in household production, then the total output they produce is the sum of the outputs they could produce separately. ${ }^{25}$ More precisely, the additivity assumption postulates that total output is the sum of the outputs the spouses could produce unilaterally when nonlabor inputs are allocated between them so as to maximize output. ${ }^{26}$ Additivity implies that the output of each spouse is independent of the time the other spouse allocates to household production. For some nonadditive household technologies (e.g., the CobbDouglas), time inputs by both spouses are essential. But even if time inputs by both spouses are not required to produce positive output, bilateral household production may be efficient. The additivity assumption rules out a wide range of household technologies, including the Cobb-Douglas. Later in this section I prove that with nonadditivity,

\footnotetext{
${ }^{25}$ This informal definition implicitly assumes that output is produced without nonlabor inputs. The formal definition is more complicated because of the need to deal with nonlabor inputs.

${ }^{26}$ In Pollak (2012) I incorrectly claim that Becker's analysis of specialization "implicitly assumes that household technology satisfies the additivity assumption."
} 
efficiency may require bilateral household production and, for some wage rates, nonspecialization. With additivity, bilateral production implies that spouses produce "side-by-side," each using his or her unilateral technology. When there are no nonlabor inputs, the additivity assumption simplifies to

$$
\mathrm{g}\left[\mathrm{t}_{\mathrm{h}}, \mathrm{t}_{\mathrm{w}}\right]=\mathrm{g}\left[\mathrm{t}_{\mathrm{h}}, 0\right]+\mathrm{g}\left[0, \mathrm{t}_{\mathrm{w}}\right]
$$

In Pollak (2012) I show that additivity and perfect substitutes are compatible only in a narrow class of cases.

The additivity assumption requires scrupulously maintaining the distinction between the household production function and the spouses' unilateral production functions. For example, the Cobb-Douglas household production function is given by

$$
\mathrm{g}\left[\mathrm{t}_{\mathrm{h}}, \mathrm{t}_{\mathrm{w}}, \mathrm{y}\right]=\mathrm{At}_{\mathrm{h}}{ }^{\beta \mathrm{h}} \mathrm{t}_{\mathrm{w}}{ }^{\beta \mathrm{w}} \mathrm{y}^{\gamma} .
$$

The unilateral production functions corresponding to the Cobb-Douglas household production function are given by

$$
\mathrm{g}\left[\mathrm{t}_{\mathrm{h}}, 0, \mathrm{y}_{\mathrm{h}}\right]=0
$$

and

$$
\mathrm{g}\left[0, \mathrm{t}_{\mathrm{w}}, \mathrm{y}_{\mathrm{w}}\right]=0 .
$$

That is, the unilateral production functions corresponding to the Cobb-Douglas household production function produce 0 output -- not a surprise, because the Cobb-Douglas household production function yields 0 output unless both spouses' time inputs are positive. 
With additivity, the spouses' unilateral production functions contain all the information required to construct the household production function. That is, with additivity the spouses' unilateral production functions are a sufficient statistic for the household production function. For example, if we assume that the household production function is additive, and if we begin with Cobb-Douglas unilateral production functions

$$
\mathrm{g}^{\mathrm{h}}\left[\mathrm{t}_{\mathrm{h}}, 0, \mathrm{yh}_{\mathrm{h}}\right]=\mathrm{A}_{\mathrm{h}} \mathrm{t}_{\mathrm{h}}{ }^{\delta \mathrm{h}} \mathrm{y}_{\mathrm{h}}{ }^{\mathrm{eh}}
$$

and

$$
\mathrm{g}^{\mathrm{w}}\left[0, \mathrm{t}_{\mathrm{w}}, \mathrm{y}_{\mathrm{w}}\right]=\mathrm{A}_{\mathrm{w}} \mathrm{t}_{\mathrm{w}}{ }^{\delta \mathrm{w}} \mathrm{y}_{\mathrm{w}}{ }^{\mathrm{kw}}
$$

then the household production function is given by

$$
\mathrm{g}\left[\mathrm{t}_{\mathrm{h}}, \mathrm{t}_{\mathrm{w}}, \mathrm{y}\right]=\max \left\{\mathrm{A}_{\mathrm{h}} \mathrm{t}_{\mathrm{h}}{ }^{\delta \mathrm{h}} \mathrm{y}_{\mathrm{h}}{ }^{\varepsilon h}+\mathrm{A}_{\mathrm{w}} \mathrm{t}_{\mathrm{w}}{ }^{\delta \mathrm{w}} \mathrm{y}_{\mathrm{w}}{ }^{\varepsilon \mathrm{w}}\right\}
$$

subject to

$$
\mathrm{y}_{\mathrm{h}}+\mathrm{y}_{\mathrm{w}} \leq \mathrm{y} .
$$

The implied household production function is not Cobb-Douglas and does not exhibit strong essentiality.

Additivity is a useful special case for household production for two reasons.

First, because additivity is tractable it provides a ready source of transparent examples and counterexamples. Second, the additive case provides an alternative to Becker's interpretation of the assumption that spouses are "intrinsically identical." Becker interprets "intrinsically identical" to mean that spouses' time inputs are perfect substitutes 
in household production. The additive case in which spouses have identical unilateral production functions provides an alternative interpretation of "intrinsically identical."

Although additivity may have been plausible for international trade in the 18th and early 19th centuries, it is implausible for households. ${ }^{27}$ For households, we want to leave open the possibility that bilateral production yields output greater than the sum of the outputs the spouses could produce unilaterally. For example, spouses might produce greater output if they were able to divide household production into component tasks, mirroring within the household the division of labor that Adam Smith observed in the pin factory.

Without additivity, efficiency may require nonspecialization. The Cobb-Douglas household production function provides a simple example. Suppose that the household technology is given by

$$
\mathrm{g}\left[\mathrm{t}_{\mathrm{h}}, \mathrm{t}_{\mathrm{w}}, \mathrm{y}\right]=\mathrm{At}_{\mathrm{h}}{ }^{\beta \mathrm{h}} \mathrm{t}_{\mathrm{w}}{ }^{\beta \mathrm{w}} \mathrm{y}^{\gamma}
$$

where $\mathrm{A}=1, \gamma=0$, and $\beta_{\mathrm{h}}=\beta_{\mathrm{w}}=1 / 2$. That is, the household commodity is produced by time alone and the spouses are equally productive. Suppose that $T_{h}=T_{w}=1$, so that each spouse has one unit of time to be allocated between household production $\left(\mathrm{t}_{\mathrm{h}}, \mathrm{t}_{\mathrm{w}}\right)$ and market work $\left(t_{\mathrm{h} 0}, \mathrm{t}_{\mathrm{w} 0}\right)=\left(1-\mathrm{t}_{\mathrm{h}}, 1-\mathrm{t}_{\mathrm{w}}\right\}$. With no nonlabor income and the price of the market good normalized to 1 , the market good is given by

$$
\mathrm{x}=\mathrm{w}_{\mathrm{h}} \mathrm{t}_{\mathrm{h} 0}+\mathrm{w}_{\mathrm{w}} \mathrm{t}_{\mathrm{w} 0}=\mathrm{w}_{\mathrm{h}}\left(1-\mathrm{t}_{\mathrm{h}}\right)+\mathrm{w}_{\mathrm{w}}\left(1-\mathrm{t}_{\mathrm{w}}\right) .
$$

\footnotetext{
${ }^{27}$ Additivity is a standard assumption in international economics. The Ricardian model of comparative advantage begins with each country's unilateral production function for each good (e.g., cloth; wine). The world's production function is the sum over all countries of these unilateral production functions. This assumes that all factors other than labor are mobile. Unless we also assume that the unilateral production
} 
Suppose the spouses' wage rates are $\mathrm{w}_{\mathrm{h}}=\mathrm{w}_{\mathrm{w}}=1$, and consider the symmetric nonspecialized time allocation $t_{h}=t_{w}=1 / 4$. This time allocation implies $\mathrm{z}=1 / 4$ and $\mathrm{x}=$ $3 / 2$, so the vector $(\mathrm{z}, \mathrm{x})=(1 / 4,3 / 2)$ is feasible. But the vector $(\mathrm{z}, \mathrm{x})=(1 / 4,3 / 2)$ cannot be produced with specialization, contrary to any general claim that efficiency requires specialization. When $\mathrm{w}_{\mathrm{h}}=\mathrm{w}_{\mathrm{w}}=1$, both spouses must allocate time to the market to satisfy $\mathrm{w}_{\mathrm{h}} \mathrm{t}_{\mathrm{h} 0}+\mathrm{w}_{\mathrm{w}} \mathrm{t}_{\mathrm{w} 0}=\mathrm{w}_{\mathrm{h}}\left(1-\mathrm{t}_{\mathrm{h}}\right)+\mathrm{w}_{\mathrm{w}}\left(1-\mathrm{t}_{\mathrm{w}}\right)=3 / 2$. And both spouses must allocate time to household production to produce $\mathrm{z}=1 / 4$.

This counterexample to the general specialization claim is not a razor's edge case.

It is easy to see that efficiency requires nonspecialization as we vary the parameters $\left(\beta_{\mathrm{h}}\right.$, $\left.\beta_{\mathrm{w}}, \mathrm{w}_{\mathrm{h}}, \mathrm{w}_{\mathrm{w}}\right)$ where $\beta_{\mathrm{w}}=1-\beta_{\mathrm{h}}$ in a neighborhood of $\left(\beta_{\mathrm{h}}, \beta_{\mathrm{w}}, \mathrm{w}_{\mathrm{h}}, \mathrm{w}_{\mathrm{w}}\right)=(1 / 2,1 / 2,1$, $1)$.

\section{A New Specialization Theorem}

In this section I prove a new specialization theorem. ${ }^{28}$

Theorem: In the absence of process preferences, if the household technology is additive and exhibits constant returns to scale, then efficiency implies specialization. ${ }^{29}$

This establishes that the class of technologies for which efficiency implies specialization is broader than perfect substitutes. ${ }^{30}$

\footnotetext{
functions of all countries are identical, this assumption is not as restrictive as at first appears because nonmobile factors can be incorporated in the unilateral production functions.

${ }^{28}$ For the remainder of this paper, I assume the absence of process preferences.

${ }^{29}$ This assumes that the efficient allocation of time to maximize $g\left[t_{h}, t_{w}, y\right]$ holding direct consumption of the market good constant is unique. Nonuniqueness arises, for example, if spouses have identical wage rates and identical constant returns to scale production functions. With nonuniqueness, any output vector that can be produced efficiently with nonspecialization can be produced efficiently with specialization. See footnote 31 .

${ }^{30}$ If output is produced by labor alone (i.e., without market goods as inputs), then additivity and constant returns to scale imply that the unilateral production functions are given by $g^{\mathrm{h}}\left[\mathrm{t}_{\mathrm{h}}, 0, \mathrm{y}_{\mathrm{h}}\right]=\mathrm{A}_{\mathrm{h}} \mathrm{t}_{\mathrm{h}}$ and $\mathrm{g}^{\mathrm{w}}\left[0, \mathrm{t}_{\mathrm{w}}, \mathrm{y}_{\mathrm{w}}\right]$ $=\mathrm{A}_{\mathrm{w}} \mathrm{t}_{\mathrm{w}}$. With additivity these unilateral production functions imply that spouses labor inputs are perfect substitutes.
} 
Proof: Suppose, on the contrary, that nonspecialization is efficient. Efficient allocations maximize the output of the household commodity, subject to appropriate constraints (see below). Hence, the program

$$
\mathrm{M}=\mathrm{M}\left[\mathrm{t}_{\mathrm{h}}, \mathrm{y}_{\mathrm{h}}, \mathrm{t}_{\mathrm{w}}, \mathrm{y}_{\mathrm{w}}\right]=\max \left\{\mathrm{g}^{\mathrm{h}}\left[\mathrm{t}_{\mathrm{h}}, 0, \mathrm{y}_{\mathrm{h}}\right]+\mathrm{g}^{\mathrm{w}}\left[0, \mathrm{t}_{\mathrm{w}}, \mathrm{y}_{\mathrm{w}}\right]\right\}
$$

subject to the constraint

$$
\mathrm{y}_{\mathrm{h}}+\mathrm{y}_{\mathrm{w}}+\mathrm{x}^{* *} \leq \mathrm{w}_{\mathrm{h}}\left(\mathrm{T}_{\mathrm{h}}-\mathrm{t}_{\mathrm{h}}\right)+\mathrm{w}_{\mathrm{w}}\left(\mathrm{T}_{\mathrm{w}}-\mathrm{t}_{\mathrm{w}}\right)+\mathrm{x}^{*}
$$

has an interior solution -- that is, a soluton satisfying

$$
0<\mathrm{t}_{\mathrm{h}}<\mathrm{T}_{\mathrm{h}} \text { and } 0<\mathrm{t}_{\mathrm{w}}<\mathrm{T}_{\mathrm{w}} \text {. }
$$

The term $\mathrm{x}^{* *}$ is the required output of the market good that is consumed directly. Thus, $\mathrm{x}^{* *}=0$ corresponds to the case in which the market good does not enter the spouses' utility functions, but serves only as an input into the production of the commodity, z.

From the first order conditions

$$
\frac{\frac{\partial \mathrm{g}^{\mathrm{h}}\left[\mathrm{t}_{\mathrm{h}}, 0, \mathrm{y}_{\mathrm{h}}\right]}{\partial \mathrm{t}_{\mathrm{h}}}}{\frac{\partial \mathrm{g}^{\mathrm{h}^{\mathrm{h}}\left[\mathrm{t}_{\mathrm{h}}, 0, \mathrm{y}_{\mathrm{h}}\right]}}{\partial \mathrm{y}_{\mathrm{h}}}}=\mathrm{w}_{\mathrm{h}}
$$

Because $\mathrm{g}^{\mathrm{h}}\left[\mathrm{t}_{\mathrm{h}}, 0, \mathrm{y}_{\mathrm{h}}\right]$ is homogeneous of degree 1 , the marginal rate of substitution is homogeneous of degree 0 . Hence, for values of $\left\{t_{h}, y_{h}\right\}$ satisfying the first order conditions we have 
$\mathrm{y}_{\mathrm{h}}=\mu^{\mathrm{h}}\left(\mathrm{w}_{\mathrm{h}}\right) \mathrm{t}_{\mathrm{h}}$.

By an analogous argument

$\mathrm{y}_{\mathrm{w}}=\mu^{\mathrm{w}}\left(\mathrm{w}_{\mathrm{w}}\right) \mathrm{t}_{\mathrm{w}}$.

Substituting for $\mathrm{y}_{\mathrm{h}}$ and $\mathrm{y}_{\mathrm{w}}$ in the constraint yields

$$
\mathrm{w}_{\mathrm{h}}\left(\mathrm{T}_{\mathrm{h}}-\mathrm{t}_{\mathrm{h}}\right)+\mathrm{w}_{\mathrm{w}}\left(\mathrm{T}_{\mathrm{w}}-\mathrm{t}_{\mathrm{w}}\right)=\mu^{\mathrm{h}}\left(\mathrm{w}_{\mathrm{h}}\right) \mathrm{t}_{\mathrm{h}}+\mu^{\mathrm{w}}\left(\mathrm{w}_{\mathrm{w}}\right) \mathrm{t}_{\mathrm{w}}+\mathrm{x}^{* *}-\mathrm{x}^{*} .
$$

Because the constraint is linear in $\left\{t_{h}, t_{w}\right\}$, we can solve it for $t_{w}$ as a linear function of $t_{h}$.

Substituting for $\mathrm{y}_{\mathrm{h}}$ and $\mathrm{y}_{\mathrm{w}}$ in the maximand yields

$$
\mathrm{M}=\mathrm{M}^{*}\left[\mathrm{t}_{\mathrm{h}}, \mathrm{w}_{\mathrm{h}}, \mathrm{t}_{\mathrm{w}}, \mathrm{w}_{\mathrm{w}}\right]=\max \left\{\mathrm{g}^{\mathrm{h}}\left[\mathrm{t}_{\mathrm{h}}, 0, \mu^{\mathrm{h}}\left(\mathrm{w}_{\mathrm{h}}\right) \mathrm{t}_{\mathrm{h}}\right]+\mathrm{g}^{\mathrm{w}}\left[0, \mathrm{t}_{\mathrm{w}}, \mu^{\mathrm{w}}\left(\mathrm{w}_{\mathrm{w}}\right) \mathrm{t}_{\mathrm{w}}\right]\right\} .
$$

Because the unilateral production functions are homogeneous of degree 1 , this becomes

$$
M=M^{*}\left[t_{h}, w_{h}, t_{w}, w_{w}\right]=\max \left\{t_{h} g^{h}\left[1,0, \mu^{h}\left(w_{h}\right)\right]+t_{w} g^{w}\left[0,1, \mu^{w}\left(w_{w}\right)\right]\right\} .
$$

That is, the maximand is a linear function of $\left\{\mathrm{t}_{\mathrm{h}}, \mathrm{t}_{\mathrm{w}}\right\}$.

Because the constraint implies that $t_{w}$ is a linear function of $t_{h}$, we can eliminate $t_{w}$ from the maximand and write it as a linear function of $t_{h}$. Hence, the program has a corner solution (i.e., either $t_{h}=0$ or $t_{h}=T_{h}$ ). ${ }^{31}$ This implies specialization, contrary to our initial assumption of nonspecialization.

\footnotetext{
${ }^{31}$ This argument implicitly assumes that $\mathrm{g}^{\mathrm{h}}\left[1,0, \mu^{\mathrm{h}}\left(\mathrm{w}_{\mathrm{h}}\right)\right] \neq \mathrm{g}^{\mathrm{w}}\left[0,1, \mu^{\mathrm{w}}\left(\mathrm{w}_{\mathrm{w}}\right)\right.$. Equality corresponds to the case discussed in footnote 29 in which the efficient allocation of time is not unique.
} 


\section{Returns to Scale}

Increasing returns and decreasing returns raise different issues. In this section I discuss both increasing returns and decreasing returns under the assumption that spouses' stocks of human capital are fixed. Becker (1991, Theorem 2.4) claims that if households can optimally adjust spouses' stocks of human capital, then perfect substitutes and increasing returns imply strong specialization (i.e., one spouse works only in the market and the other only in the household, or both spouses work only in the same sector). I show in section 6 that the validity of Becker's strong specialization claim depends on additional, unstated assumptions about the strength of human capital effects on wage rates and on productivity in the household. In section 4a I establish a result I will use in section 6. Specifically, in section 4a I show that if spouses' stocks of human capital are fixed, then perfect substitutes and increasing returns do not imply strong specialization.

In section $4 \mathrm{~b}$ I investigate whether the specialization theorem of section 3 (i.e., with additivity and constant returns, efficiency implies specialization) holds when we replace constant returns with decreasing returns. ${ }^{32}$ I show that this generalization of the theorem does not hold: with decreasing returns efficiency may require bilateral household production and, for some wage rates, nonspecialization. I argue that decreasing returns are plausible if individuals' productivities decline as spouses become tired or bored with an activity. That is, with additivity and decreasing returns, efficiency may require nonspecialization.

\footnotetext{
${ }^{32}$ I ignore the perfect substitutes case because with perfect substitutes, efficiency implies specialization regardless of assumptions about returns to scale.
} 


\section{4a. Increasing Returns to Scale and Strong Specialization}

In this section I construct a transparent counterexample to demonstrate that when each spouse's stocks of human capital are fixed, with perfect substitutes and increasing returns, efficiency need not require strong specialization. ${ }^{33}$ The intuition is straightforward and has nothing to do with increasing returns: suppose that allocating the time of either spouse exclusively to household sector results in "too much" of the household commodity and "not enough" of the market good. Hence, efficiency requires that the spouse who allocates time to the household sector also allocates time to the market sector, ruling out strong specialization. ${ }^{34}$

With strong specialization there are 4 possible patterns of time allocation, $\left(t_{h}, t_{w}\right)$, and, corresponding to each, an "output vector," $(\mathrm{z}, \mathrm{x})$. Two of these four patterns of time allocation correspond to superstrong specialization (i.e., both spouses allocate all of their time to the same sector). ${ }^{35}$ Superstrong specialization implies that the corresponding output vectors are of the form $(0, \mathrm{x})$ or $\left(\mathrm{z}, \mathrm{x}^{*}\right)$, where $\mathrm{x}^{*}$ is nonlabor income. ${ }^{36}$ That is, either both spouses work in the market and neither works in the household, or both spouses work in the household and neither works in the market. In the two remaining patterns of strong specialization, one spouse works only in the household and the other works only in the market.

\footnotetext{
${ }^{33}$ While I assume here that spouses' stocks of human capital are fixed, Becker assumes that spouses' stocks of human capital are optimally adjusted. Hence, my counterexample here does not contradict Becker's strong specialization claim.

${ }^{34}$ This assumes strictly positive production of the household commodity. "Too much" and "not enough" reflect implicit assumptions about preferences. The simplest such assumption is that the spouses have identical homothetic preferences so that production decisions are independent of Pareto weights and bargaining power.

${ }^{35}$ Recall that strong specialization includes superstrong specialization.

${ }^{36}$ The argument could be simplified by assuming that the household must pay for market goods with current earnings, but this assumption would rule out couples in which both spouses were fully retired.
} 
To proceed further, I introduce assumptions that allow me to discuss time allocation and Pareto-efficient consumption patterns without becoming bogged down in extraneous issues involving spouses' preferences, the household governance structure, and bargaining. Specifically, I assume that both the household commodity and the market good are household public goods and that spouses have identical fixed-coefficient preferences. ${ }^{37}$ The focus on this special case is legitimate because I am not proving a general theorem but constructing a counterexample to the claim that with perfect substitutes and increasing returns, efficiency implies strong specialization.

The case of superstrong specialization in which $\left(t_{h}=0, t_{w}=0\right)$, which corresponds to the output vector $(0, \mathrm{x})$, is easily dispatched. This time allocation cannot be Pareto efficient because (i) there are feasible consumption vectors in which both the household commodity and the market good are strictly positive and (ii) with fixed-coefficient preferences, any such a consumption vector dominates every consumption vector in which $\mathrm{z}=0$. I now consider the three remaining cases.

All three of the remaining cases allow strictly positive consumption of both the home-produced commodity and the market good. The first of these corresponds to the case of superstrong specialization in which the output vector is of the form $\left(\mathrm{z}, \mathrm{x}^{*}\right){ }^{38}$ The second corresponds to the time allocation in which the husband allocates time only to the market and the wife allocates time only to the household, $\left(t_{h}=0, t_{w}=1\right)$. The third corresponds to

\footnotetext{
${ }^{37}$ If spouses have fixed-coefficient preferences then any consumption vector with positive consumption of both the market good and the household commodity is preferred to every consumption vector in which $\mathrm{z}=$ 0 or $\mathrm{x}=0$. This is true for all CES preferences with an elasticity of substitution between the fixedcoefficient and Cobb-Douglas cases. The assumptions that spouses have identical preferences and that the household commodity and the market good are household public goods implies that spouses always agree about which consumption vector, output vector, and time allocation is best. In this case the governance structure is irrelevant because the spouses never disagree.

${ }^{38}$ Provided nonlabor income is not 0 , this is consistent with positive consumption of both the household commodity and the market good.
} 
the mirror image case in which the wife allocates time only to the market and the husband allocates time only to the household, $\left(t_{h}=1, t_{w}=0\right) .{ }^{39}$

I now sketch a counterexample. The intuition is straightforward. If the strong specialization claim holds for all increasing returns technologies and all well-behaved preferences, it must hold for:

(1) all increasing returns technologies that imply feasible sets with frontiers that are close to linear

(2) all preferences that allow little or no substitution between the market good and the household commodity (e.g., fixed-coefficient preferences), and in which the desired ratio of the market good to the household commodity is large.

Suppose output is produced by time alone and that the unilateral production functions are of the form

$$
\mathrm{g}\left[\mathrm{t}_{\mathrm{h}}, 0\right]=\mathrm{A}_{\mathrm{h}}\left(\mathrm{t}_{\mathrm{h}}\right)^{\delta \mathrm{h}} \text { and } \mathrm{g}\left[0, \mathrm{t}_{\mathrm{w}}\right]=\mathrm{A}_{\mathrm{w}}\left(\mathrm{t}_{\mathrm{w}}\right)^{\delta \mathrm{w}} \text {. }
$$

Increasing returns corresponds to the case in which the exponents $\delta \mathrm{h}$ and $\delta \mathrm{w}$ are greater than 1. The implied feasible set is nonconvex, but if $\delta \mathrm{h}$ and $\delta \mathrm{w}$ are close to 1 , then the feasible set is close to convex and its frontier close to linear.

Suppose preferences are given by

$$
\mathrm{U}(\mathrm{z}, \mathrm{x})=\min \{\mathrm{rz}, \mathrm{x}\},
$$

where $\mathrm{r}$ is a preference parameter. With a linear budget constraint, as the preference parameter $\mathrm{r}$ gets large, the optimal $\mathrm{x}$ gets large relative to $\mathrm{z}$. With fixed coefficient

\footnotetext{
${ }^{39}$ The second case may dominate the third, or vice versa, in the sense that the consumption vector implied by one may dominate the consumption vector implied by the other. When this is the case, efficiency implies that we can disregard the time allocation corresponding to the dominated consumption vector. Dominance arises if, for example, the husband's wage rate is greater than the wife's, the wife's productivity in the household is greater than the husband's, and $T_{h}=T_{w}$. In this case, strong specialization with the wife allocating time only to the market and the husband allocating time only to the household is inefficient.
} 
preferences, however, boundary solutions (i.e., those in which either $\mathrm{z}=0$ or $\mathrm{x}=0$ ) are never optimal.

This counterexample shows that, unlike the conclusions of Becker's other specialization theorems, the strong specialization conclusion of Theorem 2.4 does not hold when each spouse's stocks of human capital are fixed at arbitrary levels. The intuition is straightforward: with strong specialization, the scope for reallocating time is tightly constrained: only 4 patterns of time allocation are consistent with strong specialization. Thus, if the strong specialization conclusion of Theorem 2.4 is correct, the ability of households to adjust spouses' stocks of human capital must be crucial. In section 6 I show that when households can optimally adjust spouses' stocks of human capital, whether perfect substitutes and increasing returns imply strong specialization depends on the strength of human capital effects on wage rates and on productivity in the household.

\section{4b. Decreasing Returns to Scale and Specialization ${ }^{40}$}

In this section I show that, with additivity and decreasing returns, Pareto efficiency can require nonspecialization. ${ }^{41}$ That is, the specialization theorem of section 3 ceases to hold when constant returns is replaced by decreasing returns. I then argue that decreasing returns are plausible. Specifically, if individuals become tired or bored as they devote more time to an activity (e.g., child care), and if fatigue or boredom causes them to become less productive, then the unilateral production functions and the household production function are likely to exhibit decreasing returns to scale. ${ }^{42}$

\footnotetext{
${ }^{40}$ For the remainder of this section I assume additivity.

${ }^{41}$ I do not discuss perfect substitutes because with perfect substitutes Pareto efficiency implies specialization regardless of assumptions about returns to scale.

${ }^{42}$ The assumption that productivity declines as individuals become tired or bored is distinct from process preferences, although both productivity and preference effects can operate simultaneously. Whether they operate separately or together, productivity effects and preference effects may cause a Pareto-efficient household to allocate less time to activities with which individuals become tired or bored. The disutility
} 
To illustrate decreasing returns to scale, suppose that output is produced by time alone, and that the unilateral production functions are of the form

$$
\mathrm{g}\left[\mathrm{t}_{\mathrm{h}}, 0\right]=\mathrm{A}_{\mathrm{h}}\left(\mathrm{t}_{\mathrm{h}}\right)^{\delta \mathrm{h}} \text { and } \mathrm{g}\left[0, \mathrm{t}_{\mathrm{w}}\right]=\mathrm{A}_{\mathrm{w}}\left(\mathrm{t}_{\mathrm{w}}\right)^{\delta \mathrm{w}} \text {. }
$$

Decreasing returns corresponds to the case in which the exponents $\delta \mathrm{h}$ and $\delta \mathrm{w}$ are less than 1. For definiteness, I assume $\delta \mathrm{h}=\delta \mathrm{w}=1 / 2$ and $A_{h}=A_{w}$.

If there is no nonlabor income $\left(x^{*}=0\right)$, in the market sector we have

$$
\mathrm{x}=\mathrm{w}_{\mathrm{h}} \mathrm{t}_{\mathrm{h} 0}+\mathrm{w}_{\mathrm{w}} \mathrm{t}_{\mathrm{w} 0}=\mathrm{w}_{\mathrm{h}}\left(\mathrm{T}_{\mathrm{h}}-\mathrm{t}_{\mathrm{h}}\right)+\mathrm{w}_{\mathrm{w}}\left(\mathrm{T}_{\mathrm{w}}-\mathrm{t}_{\mathrm{w}}\right) .
$$

Assuming $\mathrm{T}_{\mathrm{h}}=\mathrm{T}_{\mathrm{w}}=1$, this becomes

$$
\mathrm{x}=\mathrm{w}_{\mathrm{h}}\left(1-\mathrm{t}_{\mathrm{h}}\right)+\mathrm{w}_{\mathrm{w}}\left(1-\mathrm{t}_{\mathrm{w}}\right)
$$

Suppose the spouses' wage rates are $\mathrm{w}_{\mathrm{h}}=\mathrm{w}_{\mathrm{w}}=1$, and consider the symmetric nonspecialized time allocation $t_{h}=t_{w}=1 / 4$. It is straightforward to calculate that $(z, x)=$ $(1,3 / 2)$.

This output cannot be produced with specialization. It is easy to verify that it cannot be produced with strong specialization. There are two cases of weak specialization to consider: (1) both spouses allocate time to the market and only one allocates time to home production and (2) both spouses allocate time to home production and only one allocates time to the market.

(1) Suppose only one spouse (for definiteness, the wife) allocates time to home production. Then to produce $\mathrm{z}=1$, she must allocate all of her time to home production. But when all remaining time (i.e., in this example, all of the husband's time) is allocated 
to the market sector, he cannot earn enough to purchase $x=3 / 2$. Instead we have $x=$ $\mathrm{w}_{\mathrm{h}} \mathrm{t}_{\mathrm{h} 0}=1<3 / 2$

(2) Now suppose only one spouse (for definiteness, the husband) allocates time to the market. Even if the husband allocates all of his time to the market sector, he cannot earn enough to purchase $x=3 / 2$. Instead we have $x=w_{h} t_{h 0}=1<3 / 2$. Because the example is symmetric, the same is true if we reverse the roles of husband and wife.

In this example, efficiency requires nonspecialization (i.e., both spouses must allocate time to both sectors). This nonspecialization example is not a razor's edge case: efficiency requires nonspecialization as the parameters $\left(\delta_{\mathrm{h}}, \delta_{\mathrm{w}}, \mathrm{w}_{\mathrm{h}}, \mathrm{w}_{\mathrm{w}}\right)$ vary in a neighborhood of $\left(\delta_{\mathrm{h}}, \delta_{\mathrm{w}}, \mathrm{w}_{\mathrm{h}}, \mathrm{w}_{\mathrm{w}}\right)=(1 / 2,1 / 2,1,1)$. That is, even with additivity, if both spouses' unilateral production functions exhibit decreasing returns, then efficiency may require nonspecialization. ${ }^{43}$

Decreasing returns are plausible. The effect of fatigue or boredom on productivity is well documented and provides the primary rationale for regulating the working hours of airline pilots, air-traffic controllers, and truck drivers. ${ }^{44}$ When output is produced by time alone, the negative productivity effects of fatigue and boredom imply that increases in hours worked yield less than proportional increases in output. When output requires both time and nonlabor inputs, the implications for returns to scale depend on how nonlabor inputs enter the production function. The leading case, however, is one in which

\footnotetext{
${ }^{43}$ The effect of a progressive tax on individuals' earnings is similar to decreasing returns to scale and can also lead to efficient nonspecialization even when the household technology exhibits constant returns. But with constant returns in the household technology, a progressive tax on joint earnings (i.e., the sum of individuals' earnings) cannot lead to efficient nonspecialization because taxation of joint earnings makes spouses' time in market work perfect substitutes in the "production" of the market good.

${ }^{44}$ Worker health and safety provide a secondary rationale for limiting work hours (e.g., exhausted interns and residents are more likely to stick themselves with needles, exposing them to blood-borne infectious diseases). Iglehart (2010) argues that the evidence supporting the claim that limiting the hours of medical interns and residents increases patient safety is very weak.
} 
fatigue or boredom imply decreasing returns. Two examples illustrate the possibilities and confirm that decreasing returns is the leading case. (1) Suppose that the household technology exhibits constant returns when time is measured in efficiency units and that, as individuals grow tired or bored, each additional hour produces fewer and fewer efficiency units. For definiteness, suppose that time in efficiency units is related to hours by $\mathrm{t}^{\sigma}$ where $0<\sigma<1$; hence, if time is substitutable for nonlabor inputs when time inputs are measured in hours, then the production function exhibits decreasing returns. (2) Now suppose that the household technology exhibits increasing returns when time inputs are measured in efficiency units. In this case, whether the production function exhibits decreasing, constant, or increasing returns when time inputs are measured in hours depends on the relative strength of the efficiency-units effect and the increasing returns effect as well as on the substitutability of time for nonlabor inputs. The efficiency-units effect may be offset by nonlabor inputs becoming more productive as their use increases. $^{45}$

\section{Multiple Household Production Activities}

With multiple household production activities, the sector specialization claim may fail even if spouses' time inputs are perfect substitutes in every household production activity. Suppose the household sector consists of $\mathrm{m}$ distinct activities, $\mathrm{m}>1 .{ }^{46}$ It is easy to construct examples in which both spouses allocate time to the market, one spouse allocates time to $\mathrm{m}^{*}$ household activities, and the other spouse allocates time to the remaining $\mathrm{m}-\mathrm{m}^{*}$

\footnotetext{
${ }^{45}$ The Cobb-Douglas provides a transparent example, but I omit the details.

${ }^{46}$ I assume that the household operates all $\mathrm{m}$ activities at positive levels and ignore the prior issue of which activities operate at positive levels and which at zero levels. If spouses' preferences are such that any vector with positive consumption of every commodity is preferred to every consumption vector in which one or more commodities are consumed at 0 levels, then a Pareto-efficient household will operate all $\mathrm{m}$ activities at positive levels.
} 
activities, where $\mathrm{m}^{*} \neq 0$ and $\mathrm{m}^{*} \neq \mathrm{m}$. Because the market is the only "activity" to which both spouses allocate time, this pattern of time allocation exhibits specialization. ${ }^{47}$ But it does not exhibit sector specialization because both spouses allocate time to the household sector and both spouses allocate time to the market sector. ${ }^{48}$

Because sector specialization is defined in terms of spouses' time allocation, the analysis of sector specialization does not require an aggregate measure of the output of the household sector. I finesse the issue of what constitutes a household production activity by treating the set of activities as a primitive.

The definitions of "bilateral" and "unilateral" extend to multiple household activities in the obvious way. The household sector is bilateral if both spouses allocate time to it, and unilateral if only one spouse allocates time to it. The household sector is unilateral only when all household activities are unilateral and all are performed by the same spouse. These definitions imply that with multiple household activities, the household sector is itself bilateral if one or more household activities is bilateral, or if some household activities are carried out unilaterally by the husband and others unilaterally by the wife. Subdividing a bilateral activity (e.g., "cooking") into two unilateral activities (e.g., "cooking indoors" and "cooking outdoors") has no effect on whether the household sector itself is bilateral or unilateral. $^{49}$

Efficiency may require unilateral production in the household sector for two distinct reasons. First, if the spouses are equally productive in each household activity but their

\footnotetext{
${ }^{47}$ Alternatively, the Pareto-efficient pattern of time allocation might be one in which both spouses allocate time to the same household activity and only one spouse works in the market. This pattern of time allocation implies sector specialization.

${ }^{48}$ Lundberg (2008) points out that, with multiple household activities, if spouses' time inputs are perfect substitutes, then efficiency requires activity specialization but not sector specialization.
} 
wage rates differ, then efficiency may require the lower-wage spouse to perform all household activities. This conclusion continues to hold when spouses' productivities are similar but not identical provided spouses' wage rates are sufficiently different. Second, if economies of scope knit together all household activities, then efficiency may require the same spouse to perform all of them.

Economies of scope are a property of the technology for producing two or more commodities and arise from complementarities among activities. ${ }^{50}$ Economies of scope can arise in single-person as well as in multiple-person households. Additivity, on the other hand, can arise only in multiple person households but can arise when there is only one household commodity. ${ }^{51}$

Economies of scope provide a technology-based explanation of why, with many household activities, efficiency may dictate that the same spouse perform a suite of linked activities. A number of researchers, including Becker, allude to economies of scope in household production, although without necessarily using the term. Usually the context is child care. For example, Becker (1991) writes: "...a mother can more readily feed and watch her older children while she produces additional children than while she engages in most other activities. This complementarity between bearing and rearing children has been important because, until the last century, practically all women spent most of their prime

\footnotetext{
${ }^{49}$ Indexes of "activity specialization" depend on specifying what constitutes an activity and, hence, may be affected by subdividing activities. See Bonke, Deding, Lausten, and Stratton (2008) for a rare discussion of activity specialization.

${ }^{50}$ Thus, economies of scope involve joint production. In the context of a multiproduct firm, the cost of producing the output vector $\left(\mathrm{z}_{1}, \mathrm{z}_{2}\right)$ is less than the sum of the costs of producing $\left(\mathrm{z}_{1}, 0\right)$ and $\left(0, \mathrm{z}_{2}\right)$. Panzar and Willig (1981) provide a formal cost-function definition of economies of scope and discuss the relationship between economies of scope and multiproduct firms. The standard assumption that household technology can be represented by separate production functions for each commodity precludes joint production and, hence, economies of scope. In a one person household, let $\mathrm{C}\left(\mathrm{z}_{1}, \mathrm{z}_{2}, \mathrm{y}\right)$ denote the time required to produce the commodity vector $\left(\mathrm{z}_{1}, \mathrm{z}_{2}\right)$ where $\mathrm{y}$ is the vector of nonlabor inputs. Then economics of scope imply $\mathrm{C}\left(\mathrm{z}_{1}, \mathrm{z}_{2}, \mathrm{y}\right)$ $<\min \left\{\mathrm{C}\left(\mathrm{z}_{1}, 0, \mathrm{y}_{1}\right)+\mathrm{C}\left(0, \mathrm{z}_{2}, \mathrm{y}_{2}\right)\right\}$ subject to $\mathrm{y}_{1}+\mathrm{y}_{2} \square \leq \mathrm{y}$.

${ }^{51}$ The definition of additivity in section 2 assumes no joint production.
} 
adult lives with children" (p. 38). Fafchamps and Quisumbling (2008) make a similar point, referring explicitly to economies of scope: "One common example of economies of scope is child care and house-based chores: many chores can be completed while at the same time attending to a child" (p. 3198). Hadfield (1993), criticizing Becker's analysis of the gendering of specialization, writes "...nor is there an analysis of how women's self-evident advantages in childbearing extend (presumably through economies of scope and complementarity) to create advantages in the full range of childcare household activities" $(97) .{ }^{52}$

\footnotetext{
${ }^{52}$ Unlike Hadfield, my concern is with specialization itself, not with the gendering of specialization.
} 


\section{The Roles of Human Capital}

Human capital has been the principal vehicle for introducing dynamics into household production models, although the relative importance of household human capital and market human capital is far from clear. ${ }^{53}$ Household physical capital and technical progress in household production received little attention before Greenwood, Seshadri and Yorukoglu (2005). To the extent that new household technology has been embodied in new capital goods (e.g., electric washing machines as "engines of liberation"), the explicit introduction of physical capital opens important new opportunities for empirical research. New opportunities on the theoretical side are fewer because, in the absence of market imperfections and transaction costs, the flow of services from physical capital can be treated just like the flow of inputs of market goods.

Although Becker's argument in the Treatise that "efficiency implies specialization" appears to depend on households optimally adjusting spouses' stocks of human capital, it actually does not. ${ }^{54}$ The specialization conclusion follows directly from the perfect substitutes assumption, and holds when each spouse's stocks of human capital are fixed, regardless of the level at which they are fixed. ${ }^{55}$

Human capital or, more precisely, the ability of households to adjust spouses' stocks of human capital, presents two new issues. First, when there are two kinds of human capital, household and market, we can investigate human capital specialization as well as time

\footnotetext{
${ }^{53}$ Becker and Murphy (2007) argue that "general skills are much more important in the household than in the marketplace."

${ }^{54}$ Human capital plays no role in Becker (1965).

${ }^{55}$ As I showed in section 4, Becker's claim that perfect substitutes and increasing returns to scale imply strong specialization (Theorem 2.4) does not hold when each spouse's stocks of human capital are fixed at arbitrary levels. The strength of human capital effects determine whether it holds when households optimally adjust spouses' stocks of human capital.
} 
specialization. Second, in a dynamic setting human capital strengthens the incentives for time specialization.

The definition of human capital specialization is analogous to the definition of time specialization. For example, with two types of human capital, "nonspecialization" is the case in which both spouses invest in both types of human capital. If time specialization is efficient and human capital is sector specific (i.e., market and household rather than, for example, cognitive and noncognitive), then human capital specialization is also efficient: in an efficient household, a spouse who allocates time to only one sector invests only in human capital that is specific to that sector.

For technologies that imply specialization when each spouse's stocks of human capital are fixed at arbitrary levels (e.g., perfect substitutes; additivity and constant returns to scale) human capital specialization is a consequence of time specialization, not its cause. But for household technologies that do not imply time specialization when each spouse's stocks of human capital are fixed at arbitrary levels, human capital specialization is both a consequence and a cause of time specialization: specialized time allocation and specialized investment in sector-specific human capital go hand-in-hand. They are simultaneously determined and mutually reinforcing.

For technologies that do not imply specialization when each spouse's stocks of human capital are fixed at arbitrary levels, the strength of human capital effects may play a crucial role in determining whether specialization is efficient. Although Becker does not discuss the strength of human capital effects, his functional form assumptions imply that these effects are strong. But if human capital has only weak effects on wage rates and on productivity in the household, then for given preferences and a given governance structure, 
all human capital vectors may imply the same pattern of specialization or nonspecialization.

That is, the mere presence of human capital does not automatically transform technologies for which nonspecialization is efficient into technologies for which specialization is inefficient. $^{56}$

The household's ability to optimally adjust even a single type of human capital can provide incentives for sector specialization. For example, suppose that each spouse's household human capital is fixed but the household can adjust each spouse's stock of market human capital. In this case, market human capital, through its effect on wage rates, may provide sufficient incentives for specialization. ${ }^{57}$ Except in special cases, economic theory alone cannot establish whether specialization is efficient, but it can identify the modeling assumptions and parameter values that determine whether specialization is efficient. Whether these modeling assumptions hold and whether the parameter values lie within the critical range that corresponds to specialization is an empirical question.

To say more about how human capital affects the incentives for specialization requires specifying the relationship between human capital, wage rates, and productivity in the household. Following Becker, I assume two types of human capital. But unlike Becker, who assumes sector-specific human capital (i.e., market human capital which affects only wage rates; household human capital which affects only productivity in the household), I begin by allowing both types of human capital to affect both wage rates and productivity in the household. This would be the case, for example, if one type of human capital corresponds to cognitive (c) and the other to noncognitive (n) skills, or if one type

\footnotetext{
56 When stocks of human capital are variable, it is convenient to imagine a household technology corresponding to each human capital vector.

57 The situation is much the same if there is only one type of human capital that has, for example, a greater effect on wage rates than on productivity in the household.
} 
corresponds to verbal and the other to mathematical skills. I denote the husband's human capital vector by $\left(\mathrm{H}^{\mathrm{ch}}, \mathrm{H}^{\mathrm{nh}}\right)$, and the wife's by $\left(\mathrm{H}^{\mathrm{cw}}, \mathrm{H}^{\mathrm{nw}}\right)$.

How does human capital enter the household production function? With sectorspecific human capital, the simplest assumption is that human capital is "time augmenting" in the sense that the time that each spouse allocates to a sector is multiplied by a function of that spouse's sector-specific human capital. ${ }^{58}$ I generalize this beyond the case in which human capital is sector specific by introducing sector-specific aggregator functions that convert the spouses' human capital vectors into indexes that multiply the spouses' time inputs. ${ }^{59}$ I denote the functions that aggregate the husband's human capital by $\psi^{\mathrm{h}}=\psi^{\mathrm{h}}\left[\mathrm{H}^{\mathrm{ch}}\right.$, $\left.\mathrm{H}^{\mathrm{nh}}\right]$ and $\psi^{\mathrm{h} 0}=\psi^{\mathrm{h} 0}\left[\mathrm{H}^{\mathrm{ch}}, \mathrm{H}^{\mathrm{nh}}\right]$, and those that aggregate the wife's human capital by $\psi^{\mathrm{w}}=$ $\psi^{\mathrm{w}}\left[\mathrm{H}^{\mathrm{cw}}, \mathrm{H}^{\mathrm{nw}}\right]$ and $\psi^{\mathrm{w} 0}=\psi^{\mathrm{w} 0}\left[\mathrm{H}^{\mathrm{ch}}, \mathrm{H}^{\mathrm{nh}}\right]$. These assumptions allow us to measure the time inputs that each spouse allocates to each sector in efficiency units: for the husband, $\left\{\psi^{\mathrm{h}}\left[\mathrm{H}^{\mathrm{ch}}\right.\right.$, $\left.\left.\mathrm{H}^{\mathrm{nh}}\right] \mathrm{t}_{\mathrm{h}}, \psi^{\mathrm{h} 0}\left[\mathrm{H}^{\mathrm{ch}}, \mathrm{H}^{\mathrm{nh}}\right] \mathrm{t}_{\mathrm{h} 0}\right\}$ and for the wife $\left\{\psi^{\mathrm{w}}\left[\mathrm{H}^{\mathrm{cw}}, \mathrm{H}^{\mathrm{nw}}\right] \mathrm{t}_{\mathrm{w}}, \psi^{\mathrm{w} 0}\left[\mathrm{H}^{\mathrm{cw}}, \mathrm{H}^{\mathrm{nw}}\right] \mathrm{t}_{\mathrm{w} 0}\right\}$.

Using this parametric approach, we can formalize both the substitutability of one type of human capital for the other in each sector and the strength of human capital effects. Substitutability determines the extent to which a particular type of human capital is associated with a particular sector. Sector-specific human capital is the extreme case in which neither type of human capital can substitute for the other. ${ }^{60}$ The other extreme is the linear case in which the two types of human capital are perfect substitutes.

\footnotetext{
58 This is Becker's assumption.

${ }^{59}$ A more general approach to incorporating human capital into the household production function is to allow some or all of the production function parameters to depend on the human capital vectors of both spouses, $\left\{\mathrm{H}^{\mathrm{ch}}\right.$, $\left.\mathrm{H}^{\mathrm{nh}}, \mathrm{H}^{\mathrm{cw}}, \mathrm{H}^{\mathrm{nw}}\right\}$. An even more general approach treats human capital as an argument of the household production function: $\mathrm{g}\left[\mathrm{t}_{\mathrm{h}}, \mathrm{t}_{\mathrm{w}}, \mathrm{y}, \mathrm{H}^{\mathrm{ch}}, \mathrm{H}^{\mathrm{nh}}, \mathrm{H}^{\mathrm{cw}}, \mathrm{H}^{\mathrm{nw}}\right]$.

${ }^{60}$ Uncertainty (e.g., about divorce or the death of one's spouse) creates incentives to invest in "general" rather than sector specific human capital.
} 
The strength of human capital effects depends on the range of the four aggregator functions. For example, suppose that one of the aggregator functions is bounded below by $\varphi$ - and above by $\varphi^{+}$. This assumption does not limit amount of human capital, but if the interval $\left[\varphi^{-}, \varphi^{+}\right]$is small, it severely limits the effect of human capital (e.g., on wage rates and on productivity in the household).

Given the spouses' wage rates, suppose efficiency implies bilateral household production for all admissible values of $\varphi$ (i.e., $\varphi-\leq \varphi \leq \varphi^{+}$). This implies that, given market wage rates, the effect of human capital on productivity in the household is small, perhaps sufficiently small that bilateral household production is efficient for all relevant wage rates and household technologies.

This formulation generalizes Becker's in two respects. First, Becker assumes that human capital is sector specific. In my notation, sector-specific human capital corresponds to the case in which $\left\{\psi^{\mathrm{h}}\left[\mathrm{H}^{\mathrm{ch}}\right] \mathrm{t}_{\mathrm{h}}, \psi^{\mathrm{h} 0}\left[\mathrm{H}^{\mathrm{nh}}\right] \mathrm{t}_{\mathrm{h} 0}\right\}$ and $\left\{\psi^{\mathrm{w}}\left[\mathrm{H}^{\mathrm{cw}}\right] \mathrm{t}_{\mathrm{w}}, \psi^{\mathrm{w} 0}\left[\mathrm{H}^{\mathrm{nw}}\right] \mathrm{t}_{\mathrm{w} 0}\right\}$. Second, Becker assumes that the aggregator functions are of the form

$$
\begin{aligned}
\psi^{\mathrm{h}}\left[\mathrm{H}^{\mathrm{ch}}\right] & =\mathrm{H}^{\mathrm{ch}} \\
\psi^{\mathrm{h} 0}\left[\mathrm{H}^{\mathrm{nh}}\right] & =\mathrm{H}^{\mathrm{nh}} \\
\psi^{\mathrm{w}}\left[\mathrm{H}^{\mathrm{cw}}\right] & =\mathrm{H}^{\mathrm{cw}} \\
\psi^{\mathrm{w} 0}\left[\mathrm{H}^{\mathrm{nw}}\right] & =\mathrm{H}^{\mathrm{nw}} .
\end{aligned}
$$

This functional form assumption, combined with the (time) essentiality assumption of section 2, implies that specialized household human capital is essential for household production. This functional form assumption is not a harmless normalization but a strong substantive assumption about the role of human capital. Because it maximizes human capital effects, it almost certainly exaggerates their strength. 
We have little empirical evidence about the importance of specialized human capital in household sector. We know that many older people rely on their children and grandchildren for computer support. We also know anecdotes about elderly widowers who don't know how to cook and elderly widows who don't know how to balance a checkbook. I cannot resist a Winston Churchill anecdote: "At one point ... Clementine [Winston Churchill's wife] decides that her husband can't stay at Chartwell [their country house] for the weekend as all the servants are away. 'I shall cook for myself. I can boil an egg. I've seen it done,' Churchill retorts." 61

Anecdotes aside, the importance of activity-specific or sector-specific human capital in household production is an open empirical question. Market wage rates in occupations that involve household production skills (e.g., cleaning, child care) may provide some evidence. Labor market returns to experience in these occupations are generally low. Becker's current assessment of the importance of sector-specific human capital may differ from the view he expressed in the Treatise. Becker and Murphy (2007) write:

However, returns to education and other training could still be greater in households [than in the market] if persons investing in such human capital acquired general skills that were particularly useful at household tasks. This is likely for investments in education since education improves a person's skills at processing information, preparing for future events, and managing multiple tasks. These skills are especially important in the modern household because these households perform many complicated tasks that must be coordinated (p. 33).

\footnotetext{
${ }^{61}$ Quoted by D. J. Taylor in a review of two books on Churchill in Times Literary Supplement, 14 November 2011; the quotation is from Cita Stelzer, Dinner with Churchill: The Prime Minister's Tabletop Diplomacy, Short Books, 2011).
} 
While the specialization argument in the Treatise presupposes sector-specific human capital, Becker and Murphy emphasize the importance of general rather than sector-specific human capital. $^{62}$

To summarize: although human capital is unnecessary for the specialization conclusion when spouses' time inputs are perfect substitution, or with additivity and constant returns to scale, human capital can increase the incentives for specialization. But when the household technology does not necessarily lead to specialization, the mere presence of human capital does not lead to specialization. Whether human capital actually tips the scale in favor of specialization depends on the strength of the effect of human capital on wages and on productivity in the household.

\section{Conclusion}

Economic theory alone cannot tell us whether efficiency implies specialization. For some household technologies efficiency implies specialization regardless of spouses' preferences, regardless of the household governance structure, and regardless of assumptions about the role of human capital. Becker showed that for household technologies in which spouses' time inputs are perfect substitutes, efficiency implies specialization. I have shown that for household technologies that are additive and exhibit constant returns to scale, efficiency implies specialization. Both of these results depend on assuming the absence of process preferences and assuming two sectors, household and market. Neither result depends on assuming that households optimally adjust spouses' stocks of human capital: the specialization conclusion holds when spouses' stocks of

\footnotetext{
${ }^{62}$ Becker's assumption that human capital is sector specific is an expositional devise: "I have assumed that each type of human capital raises efficiency at only a single activity, but we do not need to hold to this limitation" (p. 36).
} 
human capital are fixed at arbitrary levels. For technologies for which efficiency does not imply specialization regardless of spouses' preferences and regardless of the household governance structure, human capital increases the incentives for specialization. Whether these incentives actually lead to specialization, however, depends on the strength of human capital effects as well as on spouses' preferences and the governance structure.

Even when specialization is efficient, couples may fail to specialize. For example, inefficiency may arise if spouses are unwilling or unable to make binding intertemporal commitments. Becker makes this point in the Treatise, interpreting marriage and divorce laws as societies' attempts to provide the assurance needed to support efficient specialization and investment in human capital. Lundberg and Pollak (2003) develop and analyze a two-period model in which spouses' inability to make binding intertemporal commitments can lead to dynamic inefficiency in the context of the "two earner couple location problem." Lundberg (2008) analyzes dynamic inefficiency in a two-period model in which the failure to accumulate market human capital in the first period disadvantages a spouse in second-period bargaining.

Without binding agreements in the marriage market about allocation within marriage, specialization has strong distributional consequences. If distribution within marriage depends on bargaining in marriage and if bargaining power depends on wages or earnings, then equality in marriage requires that both spouses work in the market. But if efficiency implied specialization and both spouses work in the market, then efficiency implies that one spouse do all the housework. Many regard this as clear evidence that equity and efficiency are incompatible. ${ }^{63}$ For those of us concerned with equity as well as

\footnotetext{
${ }^{63}$ The specialized time allocation in which one spouse only works in the household also leaves the stay-athome spouse vulnerable in the long-run because of her failure to accumulate market human capital. We can
} 
efficiency and who think that bargaining takes place within marriage, it is good news that efficiency need not require specialization.

avoid this dynamic vulnerability by assuming, as Becker does in Chapter 4 of the Treatise, that prospective spouses make binding agreements in the marriage market that determine distribution in marriage. Lundberg and Pollak (2009) propose and analyze a marriage-market model in which prospective spouses cannot make binding agreements in the marriage market. Instead, the marriage market determines who marries and who marries whom, but distribution in marriage is determined by bargaining in marriage. 


\section{References}

Aguiar, Mark and Erik Hurst, "Measuring Trends in Leisure: The Allocation of Time over Five Decades," Quarterly Journal of Economics, Vol. 122, No. 3, (August 2007), 969-1006

Aguiar, Mark and Erik Hurst, "A Summary of Trends in U.S. Time Use: 1965-2005," Social Indicators Research, Vol. 98, No. 1, (August 2009), 57-64.

Becker, Gary S., "A Theory of the Allocation of Time," Economic Journal, Vol. 75, No. 299, (September 1965), 493-517.

Becker, Gary S., A Treatise on the Family, Cambridge: Harvard University Press, 1981; Enlarged edition, 1991.

Becker, Gary S. and Kevin M. Murphy, "Education and Consumption: The Effects of Education in the Household Compared to the Marketplace," Journal of Human Capital, Vol. 1, No. 1, (Winter 2007), 9-35.

Bianchi, Suzanne M., Liana C. Sayer, Melissa A. Milkie, and John P. Robinson, "Housework: Who Did, Does or Will Do It, and How Much Does It Matter?" Social Forces, Vol. 91, No. 1, (September 2012), 55-63.

Bonke, Jens, Mette Deding, Mette Lausten, and Leslie Stratton, "Intrahousehold Specialization in Housework in the United States and Denmark," Social Science Quarterly, Vol. 89, No. 4, (December 2008), 1023-1043.

Brines, Julie, "Economic Dependency, Gender, and the Division of Labor at Home," American Journal of Sociology, Vol. 100, No. 3, (November 1994), 652-688.

Burda, Michael, Daniel S. Hamermesh, and Philippe Weil, "Total Work and Gender: Facts and Possible Explanations," Journal of Population Economics, Vol. 26, No. 1, (January 2013), 239-261.

Chiappori, Pierre-André, "Rational Household Labor Supply," Econometrica, Vol. 56, No. 1, (January 1988), 63-89.

Chiappori, Pierre-André, "Collective Labor Supply and Welfare," Journal of Political Economy, Vol. 100, No. 3, (June 1992), 437-467.

Cogan, John F., "Fixed Costs and Labor Supply," Econometrica, Vol. 49, No. 4, (July 1981), 945-963.

Donald, Stephen G., and Daniel S. Hamermesh, "A Structural Model of the Fixed Time Costs of Market Work," Economics Letters, Vol. 104, No. 3, (September 2009), 125-128. 
England, Paula and Nancy Folbre, "Gender and Economic Sociology," Chapter 27 in Neil J. Smelser and Richard Swedberg, eds., Handbook of Economic Sociology, 2nd ed., Princeton: Princeton University Press, 2005, 627-649.

Fafchamps, Marcel and Agnes R. Quisumbling, "Household Formation and Marriage Markets in Rural Areas," Chapter 51 in T. Paul Schultz and John Strauss, eds., Handbook of Development Economics, Vol. 4, Amsterdam: North-Holland, 2008, 3187-3248.

Folbre, Nancy, "A Theory of the Misallocation of Time," in Nancy Folbre and Michael Bittman, eds., Family Time: The Social Organization of Care, London: Routledge, 2004, 7-24.

Gershuny, Jonathan, Changing Times: Work and Leisure in Postindustrial Society, Oxford: Oxford University Press, 2000.

Greenwood, Jeremy, Ananth Seshadri, and Mehmet Yorukoglu, "Engines of Liberation," Review of Economic Studies, Vol. 72, No. 1, (January 2005), 109-133.

Gronau, Reuben, "Leisure, Home Production, and Work -- the Theory of the Allocation of Time Revisited," Journal of Political Economy, Vol. 85, No. 6, (December 1977), 10991124.

Guryan, Jon, Erik Hurst, and Melissa Kearney, "Parental Education and Time with Children" Journal of Economic Perspectives, Vol. 22, No. 3, (summer 2008), 23-46.

Hadfield, Gillian K., "Households at Work: Beyond Labor Market Policies to Remedy the Gender Gap," Georgetown Law Journal, Vol. 82, (November 1993), 89-107.

Hamermesh, Daniel S., Harley Frazis, and Jay Stewart, "Data Watch: The American Time Use Survey," Journal of Economic Perspectives, Vol. 19, No. 1, (Winter 2005), 221-232.

Hamermesh, Daniel S. and Jungmin Lee, "Stressed out on Four Continents: Time Crunch or Yippie Kvetch?" Review of Economics and Statistics, Vol. 89, No. 2, (May 2007), 374-383.

Hochchild, Arlie and Anne Machung, The Second Shift: Working Families and the Revolution at Home, New York: Viking, 1989.

Iglehart, John K., "The ACGME's Final Duty-Hours Standards -- Special PGY-1 Limits and Strategic Napping," New England Journal of Medicine, Vol. 363, No. 17, (October 21, 2010), 1589-1591.

Juster, F. Thomas and Frank P. Stafford, "The Allocation of Time: Empirical Findings, Behavioral Models, and Problems of Measurement," Journal of Economic Literature, Vol. 29, No. 2, (June 1991), 471-522. 
Lundberg, Shelly, "Gender and Household Decision-Making," in Francesca Bettio and Alina Verashchagina, eds., Frontiers in the Economics of Gender, New York: Routledge, 2008, 116-133.

Lundberg, Shelly and Robert A. Pollak, "Separate Spheres Bargaining and the Marriage Market," Journal of Political Economy, Vol. 101, No. 6, (December 1993), 988-1010.

Lundberg, Shelly and Robert A. Pollak, "Efficiency in Marriage," Review of Economics of the Household, Vol. 1, No. 3, (September 2003), 153-168.

Lundberg, Shelly and Robert A. Pollak, "American Family and Family Economics," Journal of Economic Perspectives, Vol. 21, No. 2, (Spring 2007), 3-26.

Lundberg, Shelly and Robert A. Pollak, "Marriage Market Equilibrium and Bargaining in Marriage," March 5, 2009.

Manser, Marilyn and Murray Brown, "Marriage and Household Decision-Making: A Bargaining Analysis," International Economic Review, Vol. 21, No. 1, (February 1980), $31-44$.

McElroy, Marjorie B. and Mary J. Horney, "Nash-Bargained Household Decisions: Toward a Generalization of the Theory of Demand," International Economic Review, Vol. 22, No. 2, (June 1981), 333-349.

Panzar, John C. and Robert D. Willig, "Economies of Scope," American Economic Review, Vol. 71, No. 2, (May 1981), 268-272.

Pollak, Robert A., "Allocating Time: Individuals' Technologies, Household Technology, Perfect Substitutes, and Specialization," NBER Working Paper 17529, October 2011. Annals of Economics and Statistics, Nos. 105-106, (January/June 2012), 75-97.

Pollak, Robert A., and Michael L. Wachter, "The Relevance of the Household Production Function and Its Implications for the Allocation of Time," Journal of Political Economy, Vol. 83, No. 2, (April 1975), 255-277.

Ramey, Garey and Valerie Ramey, "The Rug Rat Race," Brookings Papers on Economic Activity, Spring 2010, 129-176.

Ramey, Valerie "Time Spent in Home Production in the 20th Century United States," Journal of Economic History, Vol. 69, (March 2009), 1-47.

Ramey, Valerie and Francis Neville, "A Century of Work and Leisure," American Economic Journal: Macroeconomics, Vol. 1, No. 2, (July 2009), 189-224. 
Rosen, Sherwin, "The Theory of Equalizing Differences," Chapter 12 in Orley C. Ashenfelter and Richard Layard, eds. Handbook of Labor Economics, Vol. 1, Amsterdam: North-Holland, 1986, 641-692.

Wax, Amy L., "Bargaining in the Shadow of the Market: Is There a Future for Egalitarian Marriage?" Virginia Law Review, Vol. 84, No. 4, (May 1998), 509-672. 


\section{Appendix: Becker's Specialization Theorems}

In this appendix I discuss the five specialization theorems from Chapter 2 ("Division of Labor in Households and Families") of the Treatise. The question is: how do these theorems rule out cases in which efficiency requires nonspecialization? The answer, which is not apparent from the statements of the theorem themselves, is the perfect substitutes assumption.

Before stating the specialization theorems formally, Becker emphasizes that his discussion assumes perfect substitutes: "A major assumption of the present section [Specialization in Households] is that at the beginning everyone is identical; differences in efficiency are not determined by biological or other intrinsic differences....Since all persons are assumed to be intrinsically identical, they supply the same kind of time to the household and market sectors. Therefore, the effective time of different members would be perfect substitutes even if they accumulate different amounts of household capital..." (p. 32; italics in original). ${ }^{64}$

Theorem 2.1 is about time specialization and Theorem 2.2 about human capital specialization. The formal statements of the theorems do not mention perfect substitutes and they impose assumptions that become redundant when the perfect substitutes assumption is added to the hypothesis.

Because these two theorems have identical hypotheses (i.e., "different comparative advantages"), I state both theorems before discussing them.

Theorem 2.1 "If all members of an efficient household have different comparative advantages, no more than one member would allocate time to both the market and

\footnotetext{
${ }^{64}$ I do not discuss whether the assumption that all persons are "intrinsically identical" implies that spouses' time inputs are perfect substitutes. Instead, I proceed as if Becker assumes perfect substitutes.
} 
household sectors. Everyone with a greater comparative advantage in the market than this member's would specialize completely in the market, and everyone with a greater comparative advantage in the household would specialize completely there" (p. 33).

Theorem 2.2 "If all members of a household have different comparative advantages, no more than one member would invest in both market and household capital. Members specializing in the market sector would invest only in market capital, and members specializing in the household sector would invest only in household capital" (p. 34).

If we include perfect substitutes in the hypothesis of Theorem 2.1, then the time specialization conclusion holds even if we remove "different comparative advantages" from its hypothesis. That is, efficiency and perfect substitutes imply specialization and "different comparative advantages" becomes redundant. ${ }^{65}$ The specialization conclusion of Theorem 2.1 holds even when each spouse's stocks of human capital are fixed at arbitrary levels, and Becker's proof does not rely on adjusting spouses' stocks of human capital.

If households optimally adjust spouses' stocks of human capital, then time specialization implies human capital specialization, so Theorem 2.2 follows from Theorem 2.1. As Becker writes: "...members specializing entirely in the market sector have strong incentives to invest in market capital $\left(\mathrm{H}^{1}\right)$ and no incentive to invest in household capital $\left(\mathrm{H}^{2}\right)$. Similarly, members specializing in the household sector have strong incentives to invest in $\mathrm{H}^{2}$ and no incentive to invest in $\mathrm{H}^{1 "}$ (p. 34).

Theorem 2.1 holds even if we do not include perfect substitutes in its hypothesis: different comparative advantages imply specialization. But the interpretation of the 
theorem as implying that specialization is pervasive depends on the implicit assumption that "different comparative advantages" is the normal case and that "equal comparative advantages" is an unlikely coincidence.

To see that the two theorems hold without assuming perfect substitutes, compare the definition of comparative advantage with the first order conditions for production efficiency. Before stating Theorem 2.1, Becker defines comparative advantage: "The comparative advantage of a [household] member can be defined by the relation between the ratio of his marginal products in the market and household sectors, and the ratios of other members" (p. 33). That is, equal comparative advantages means

$\frac{\frac{\partial g\left[t_{h}, t_{w}, y\right]}{\partial t_{h}}}{w_{h}}=\frac{\frac{\partial g\left[t_{h}, t_{w}, y\right]}{\partial t_{w}}}{w_{w}}$

The first order conditions for production efficiency arise from maximizing output

$$
\mathrm{g}\left[\mathrm{t}_{\mathrm{h}}, \mathrm{t}_{\mathrm{w}}, \mathrm{y}\right]
$$

subject to the constraint

$$
y_{h}+y_{w}+x^{* *} \leq w_{h}\left(T_{h}-t_{h}\right)+w_{w}\left(T_{w}-t_{w}\right)+x^{*} .
$$

If this maximization problem has an interior solution, then the first order conditions are

$$
\frac{\partial \mathrm{g}\left[\mathrm{t}_{\mathrm{h}}, \mathrm{t}_{\mathrm{w}}, \mathrm{y}\right]}{\partial \mathrm{t}_{\mathrm{h}}}=\lambda \mathrm{w}_{\mathrm{h}}
$$

and

\footnotetext{
${ }^{65}$ This assumes the absence of process preferences. It also requires carving out an exception for the case in which both specialization and nonspecialization are efficient (e.g., spouses have identical wages rates and are equally productive in the household).
} 


$$
\frac{\partial \mathrm{g}\left[\mathrm{t}_{\mathrm{h}}, \mathrm{t}_{\mathrm{w}}, \mathrm{y}\right]}{\partial \mathrm{t}_{\mathrm{w}}}=\lambda \mathrm{w}_{\mathrm{w}}
$$

Eliminating $\lambda$ and rearranging, yields the equal comparative advantage condition. In effect, the theorem says: If we don't have an interior solution (i.e., a solution in which both spouses allocate time to both sectors), then we have a boundary solution (i.e., a solution in which at least one spouse does not allocate time to both sectors). This paraphrase of Theorem 2.1 is not a criticism: theorems, after all, are tautologies. But the interpretation of Theorem 2.1 as implying that specialization is pervasive depends on imposing perfect substitutes or some other strong assumption.

Theorem 2.3 "At most one member of an efficient household would invest in both market and household capital and would allocate time to both sectors" (p. 34).

Theorem 2.3 depends on the perfect substitutes assumption. Indeed, unless we reinterpret Theorem 2.3 to include perfect substitutes as an hypothesis, it would have no hypothesis at all. Becker's proof of Theorem 2.3 depends on perfect substitutes and also appears to depend on assuming that the household optimally adjusts spouses' stocks of market and household human capital. In fact, however, the conclusion follows directly from the perfect substitutes assumption and holds even when each spouse's stocks of human capital are held fixed at arbitrary levels.

Theorem 2.4 makes a claim about strong specialization:

Theorem 2.4 "If commodity production functions have constant or increasing returns to scale, all members of efficient households would specialize completely in the market or 
household sectors and would invest only in market or household capital" (p. 35; italics in original).

As I showed in section 4a, the conclusion of Theorem 2.4 does not hold when each spouse's stocks of human capital are held fixed at arbitrary levels. ${ }^{66}$ But here, as elsewhere, Becker assumes that the household optimally adjusts spouses' stocks of human capital. As I argue in section 6, the analysis of specialization when the household optimally adjusts spouses' stocks of human capital requires assumptions about the strength of human capital effects on wage rates and on productivity in the household.

Theorem 2.5 addresses the case in which the number of household members exceeds the number of commodities.

Theorem 2.5 "All but possibly one member of households with more members than independent commodities would completely specialize their investments and time to the market or to a particular commodity. Moreover, with constant or increasing returns to scale, all members of efficient households must be completely specialized" (p. 36; italics in original).

The first sentence of the theorem is about weak specialization and the second about strong specialization. If we restrict our attention to the case in which the household consists of two members and there is a single home produced commodity, the first sentence becomes Theorem 2.3 and the second sentence Theorem 2.4. Thus, the theorem's value added emerges only when we expand the analyses and consider households with more than two individuals.

\footnotetext{
${ }^{66}$ The hypothesis of Theorem 2.4 is unusual: the standard assumption is that production functions are concave, and concavity implies constant or decreasing returns to scale.
} 